\title{
PROPERTIES OF THE SIMULATED COARSE-GRAINED MICROSTRUCTURE OF QUENCHED AND TEMPERED HIGH-STRENGTH STEEL
}

\section{LASTNOSTI SIMULIRANE GROBOZRNATE MIKROSTRUKTURE POBOLJŠANEGA VISOKOTRDNEGA JEKLA}

\author{
Roman Celin ${ }^{1 *}$, Fevzi Kafexhiu1, Grega Klančnik², Jaka Burja ${ }^{1}$ \\ ${ }^{1}$ Institute of Metals and Technology, Lepi pot 11, 1000 Ljubljana, Slovenia \\ ${ }^{2}$ RCJ d.o.o., Cesta Franceta Prešerna 61, 4270 Jesenice, Slovenia \\ Prejem rokopisa - received: 2020-07-28; sprejem za objavo - accepted for publication: 2020-10-05
}

doi:10.17222/mit.2020.144

\begin{abstract}
Quenched and tempered high-strength steels have a favorable strength-to-weight ratio. These steels are usually welded with the use of standard procedures. Due to the heat input during welding, steels undergo changes in the heat-affected zone and as a result an unfavorable microstructure and mechanical properties can occur. The coarse-grained heat-affected-zone microstructure was studied with the use of simulated thermal cycles. They were applied to the experimental quenched and tempered steel. The steel samples were heated to a peak temperature of $1350{ }^{\circ} \mathrm{C}$ and then cooled with different rates. A microstructure examination, dilatometry analysis and hardness measurements of the steel samples were performed. The transformation start and finish temperatures were determined using the dilatation vs. temperature data analysis. The investigation was performed to determine the appropriate cooling time $t_{8 / 5}$ interval for further investigation of the experimental steel.
\end{abstract}

Keywords: microstructure, coarse-grained, continuous cooling, hardness

Visokotrdna kaljena in popuščena jekla imajo ugodno razmerje med trdnostjo in težo. Ta jekla se lahko varijo z uporabo standardnih postopkov varjenja. Zaradi vnosa toplote med varjenjem se jeklo v toplotno vplivanem področju spremeni, zaradi česar lahko pride do neželene mikrostrukture in slabih mehanskih lastnosti. Simuliacija varilnih toplotnih ciklov je bila uporabljena za raziskavo grobo-zrnate mikrostrukture preizkusne šarže kaljenega in popuščenega jekla. Vzorci jekla so bili segreti do temperature $1350{ }^{\circ} \mathrm{C}$ in nato podvrženi različnim hitrostim ohlajanja. Izvedena je bila analiza podatkov, zabeleženih z dilatometrom, ter meritve trdote in preiskava mikrostrukture vzorcev. Za posamezne vzorce sta bili določeni temperaturi začetka in konca transformacije pri ohlajanju. Rezultati izvedenih preiskav so osnova za določitev primernega časa ohlajanja $t_{8 / 5}$ za nadaljne reziskave preizkusnega jekla.

Ključne besede: mikrostruktura, grobo zrno, kontinuirno ohlajevanje, trdota

\section{INTRODUCTION}

High-strength quenched and tempered steels are commonly referred to as Q\&T steels. They are used to simultaneously reduce the weight and increase the load capacity of load-bearing components (pressure vessels, building columns, cranes, off-shore structures, etc.). These steels are also used for the production of armored steel plates. ${ }^{1,2}$

The standard EN 10025-6 for quenched and tempered steels allows variations of the chemical composition, but with minimum requirements for the mechanical properties. ${ }^{3}$ This allows steel manufacturers to use different chemical compositions with a combination of appropriate rolling parameters and heat treatment (quenching followed by tempering) to achieve a minimum yield strength of above $1000 \mathrm{MPa}{ }^{4,5}$ The final result is typically a microstructure of tempered martensite and bainite.

*Corresponding author's e-mail: roman.celin@imt.si (Roman Celin)
Different arc-welding procedures such as shielded metal arc welding (SMAW), gas metal arc welding (GMAW), gas tungsten arc welding (GTAW) can be used for joining quenched and tempered steels. ${ }^{6}$

The properties of the weld metal and the microstructural development of the adjacent heat-affected zone (HAZ) are to a large extent influenced by the welding thermal cycle and the composition of the base material. The influence of the welding thermal cycle can be expressed through the welding heat input, which can be determined by the cooling time $t_{8 / 5}$. The cooling time is defined as the time for the temperature to drop from $800{ }^{\circ} \mathrm{C}$ to $500{ }^{\circ} \mathrm{C}$ and is in an inverse relation to the cooling rate $\left({ }^{\circ} \mathrm{C} / \mathrm{s}\right) .{ }^{7}$ The longer the $t_{8 / 5}$ (higher heat input), the slower the cooling rate is.

During welding the highest temperature, besides weld molten metal, is in the coarse-grained heat affected zone (CG HAZ) and can be above $1100{ }^{\circ} \mathrm{C} .{ }^{8}$ At that temperature the initial tempered martensite microstructure of the quenched and tempered steel undergoes an austenite transformation and the grains start to grow. If a subsequent cooling rate is high enough, martensitic and/or bainitic transformations from the austenite take place. 
The weld HAZ is narrow and difficult to investigate, so a simulation of the welding thermal cycle is used to produce a sample with a uniform CG HAZ microstructure that is suitable for investigations.

In most cases a weld thermal simulator and/or a quenching dilatometer are used for thermal cycle simulations, which are usually performed as a part of the weldability investigation for the investigated steel..$^{9,10}$ Data acquired during thermal cycle simulations are used to construct a continuous cooling transformation (CCT) diagram, which is useful to monitor the microstructure development in relation to the $t_{8 / 5}$ (cooling rate).

This study was performed with the use of a dilatometer. To conduct the continuous cooling transformation tests of the coarse-grained HAZ (CG HAZ) for the experimental steel, several simulated thermal cycles were applied. The simulation results were used to investigate the correlation among the cooling rates, CG HAZ microstructure, and hardness. The final goal was to determine the $t_{8 / 5}$ cooling time interval for the experimental steel-welding procedure.

\section{EXPERIMENTAL PART}

A steel characterization was carried out through metallographic analyses and hardness measurements. A $12-\mathrm{mm}$ plate made from the experimental laboratory steel that fulfilled the S1100Q steel designation requirements was tested. The experimental steel has the following mechanical properties: yield strength $R_{\mathrm{e}}=1186 \mathrm{MPa}$, tensile strength $R_{\mathrm{m}}=1348 \mathrm{MPa}$, and an average hardness HV5 $=446$. Figure 1 shows the tempered martensite microstructure of the experimental steel S1100 QT.

Cylindrical samples that were $4 \mathrm{~mm}$ in diameter and $10 \mathrm{~mm}$ in length were made for the welding thermal cycle simulations in the dilatometer.

A TA Instruments DIL805A/D dilatometer was employed to simulate the weld CG HAZ in an argon atmosphere. The samples were heated to the peak temperature

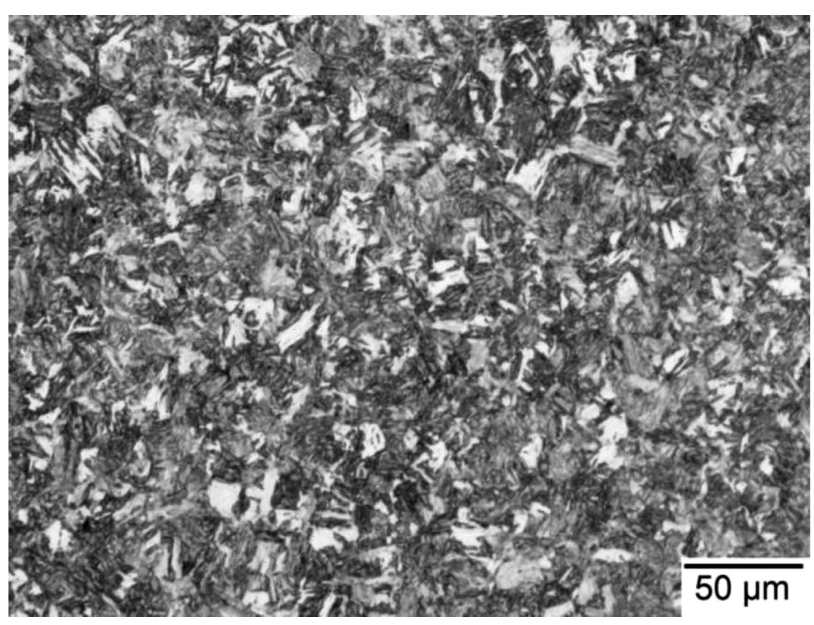

Figure 1: Tempered martensite microstructure of the S1100 Q experimental steel of $1350{ }^{\circ} \mathrm{C}$ with a heating rate of $200{ }^{\circ} \mathrm{C} / \mathrm{s}$, held at the peak temperature for $3 \mathrm{~s}$ and then cooled by applying five different time $t_{8 / 5}$ intervals ranging from $5 \mathrm{~s}$ to $80 \mathrm{~s}$ (Table 1), the cooling curve was logarithmic to simulate natural cooling during actual welding. The acquisition of the cooling-cycle data was turned off at $200{ }^{\circ} \mathrm{C}$. The thermal-cycle parameters were selected based on previous work. ${ }^{11}$

Table 1: Thermal-cycle simulation parameters

\begin{tabular}{|c|c|c|c|}
\hline Heating rate & $\begin{array}{c}\text { Peak tempera- } \\
\text { ture }\end{array}$ & Holding time & $\begin{array}{c}\text { Cooling time } \\
\Delta t_{8 / 5}\end{array}$ \\
\hline $200{ }^{\circ} \mathrm{C} / \mathrm{s}$ & $1350^{\circ} \mathrm{C}$ & $3 \mathrm{~s}$ & $\begin{array}{c}5 \mathrm{~s}, 10 \mathrm{~s}, 20 \mathrm{~s}, \\
40 \mathrm{~s}, 80 \mathrm{~s}\end{array}$ \\
\hline
\end{tabular}

The dilatation data generated during the cooling were recorded and the phase-transformation points were obtained with the tangent method. Quantitative chemical analysis of the experimental steel with a property of the S1100 QL was made using ICP spectrometry. The chemical composition in weight \% is: $0.149 \% \mathrm{C} ; 0.22 \% \mathrm{Si}$; $0.95 \% \mathrm{Mn} ; 0.003 \% \mathrm{~S} ; 0.52 \% \mathrm{Cr} ; 0.38 \% \mathrm{Cu} ; 1.31 \%$ $\mathrm{Ni} ; 0.42 \% \mathrm{Mo} ; 0.02 \% \mathrm{~V} ; 0.014 \% \mathrm{Nb} ; 0.04 \% \mathrm{~N}$; $0.0006 \% \mathrm{~B}$; and $0.046 \% \mathrm{Al}$.

Metallographic samples were prepared by grinding and polishing, followed by chemical etching in a $2 \%$ nital solution. An optical microscope (OM) Microphot FXA, Nikon and scanning electron microscope (SEM) JEOL JSM-6500F with electron backscattered diffraction (EBSD) were used for characterization of the simulated CG HAZ microstructure.

The Vickers hardness of the samples from the thermal cycle simulations was measured in accordance with EN ISO 6507-1, applying a load of $5 \mathrm{~kg}$ (HV5). The results of the hardness testing were used to plot the "Time $t_{8 / 5}$ vs. Hardness HV5" graph for the simulated CG HAZ microstructure.

\section{RESULTS AND DISCUSSION}

\subsection{Chemical composition}

To assess the influence of the chemical composition (carbon and alloying elements) on the steel's weldability, the term carbon equivalent $C E$ is used. Equation (1) from the standard EN 1011-2 $2^{12}$ is applicable to the investigated experimental low-alloy high-strength steels with a carbon equivalent designation as $C E T$ :

$$
C_{E T}=C+\frac{M n+M o}{10}+\frac{C r+C u}{20}+\frac{N i}{40}
$$

The carbon content of the experimental steel is $0.149 \%$, which ensures adequate weldability. However, a CET value of a 0.364 suggests that preheat and control of heat input during the welding process is needed to avoid the occurrence of hydrogen-induced cracking (cold (racking). ${ }^{13}$ 


\subsection{Continuous cooling transformation diagram and hardness}

The dilatometry data that were recorded during the welding thermal-cycle simulations were analyzed. The heating rate and the first stage of cooling are the same for all samples (Table 1). An increase in the temperature causes linear thermal expansion in the sample. The transformation points at the heating rate of $200{ }^{\circ} \mathrm{C} / \mathrm{s}$ were $A_{\mathrm{c} 1}=754{ }^{\circ} \mathrm{C}$ and $A_{\mathrm{c} 3}=850{ }^{\circ} \mathrm{C}$. The temperatures $A_{\mathrm{c} 1}$ and $A_{\mathrm{c} 3}$ are higher than the equilibrium temperatures $A_{\mathrm{e} 1}$ and $A_{\mathrm{e} 3}$ because of the rapid heating rate. ${ }^{14}$

During cooling, dilatation of the sample decreases linearly from $1350{ }^{\circ} \mathrm{C}$ with the decrease in temperature until it reaches the transformation start temperature. Due to the low temperatures the diffusional transformations are not possible, so the displacive transformations take place (bainitic, martensitic). The dilatation again decreases linearly with cooling to room temperature. The transformation start temperature $\left(T_{\mathrm{s}}\right)$ and the transformation finish temperature $\left(T_{\mathrm{f}}\right)$ for all the cooling rates were determined from the plots (Table 2).

Table 2: Transformation start s and transformation finish temperature

\begin{tabular}{|l|c|c|c|c|c|}
\hline \multicolumn{6}{|c|}{$t_{8 / 5}$ cooling time (s) (cooling rate $\left({ }^{\circ} \mathrm{C} / \mathrm{s}\right)$ ) } \\
\hline & $5(60)$ & $10(30)$ & $20(15)$ & $40(7.5)$ & $80(3.75)$ \\
\hline$T_{\mathrm{s}}\left({ }^{\circ} \mathrm{C}\right)$ & 412 & 413 & 420 & 448 & 476 \\
\hline$T_{\mathrm{f}}\left({ }^{\circ} \mathrm{C}\right)$ & 265 & 300 & 340 & 345 & 360 \\
\hline
\end{tabular}

The dilatation plots at the cooling stage of the simulated thermal cycles $t_{8 / 5}=5 \mathrm{~s}, 20 \mathrm{~s}$ and $80 \mathrm{~s}$ are shown in Figure 2.

Based on the dilatometry data, the cooling diagram for the simulated weld CG HAZ microstructure was constructed and is shown in Figure 3.

From Figure 3 it is clear that the transformation start and transformation finish temperature rise gradually with the increasing cooling time $t_{8 / 5}$. The transformation at continuous cooling occurs in a temperature range between $476{ }^{\circ} \mathrm{C}$ and $265{ }^{\circ} \mathrm{C}$ for all the applied cooling rates.

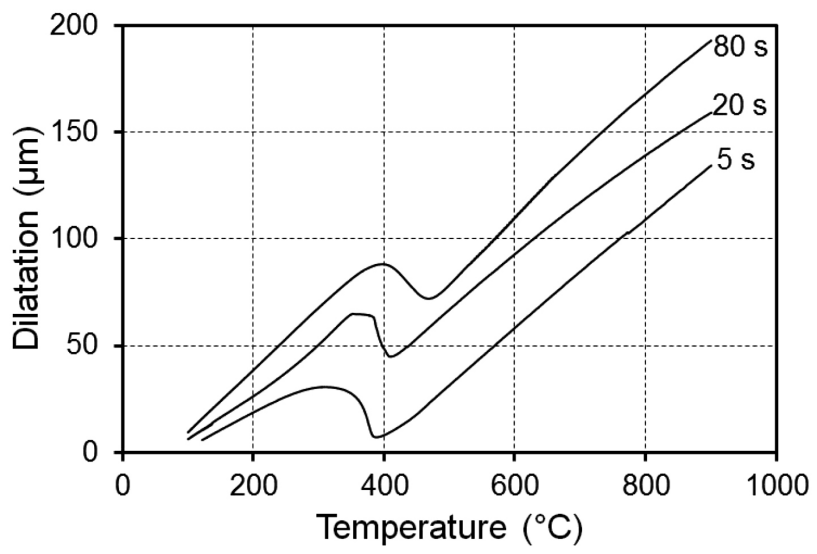

Figure 2: Dilatation vs. temperature cooling curves for the $t_{8 / 5}=5 \mathrm{~s}$, $20 \mathrm{~s}$ and $80 \mathrm{~s}$

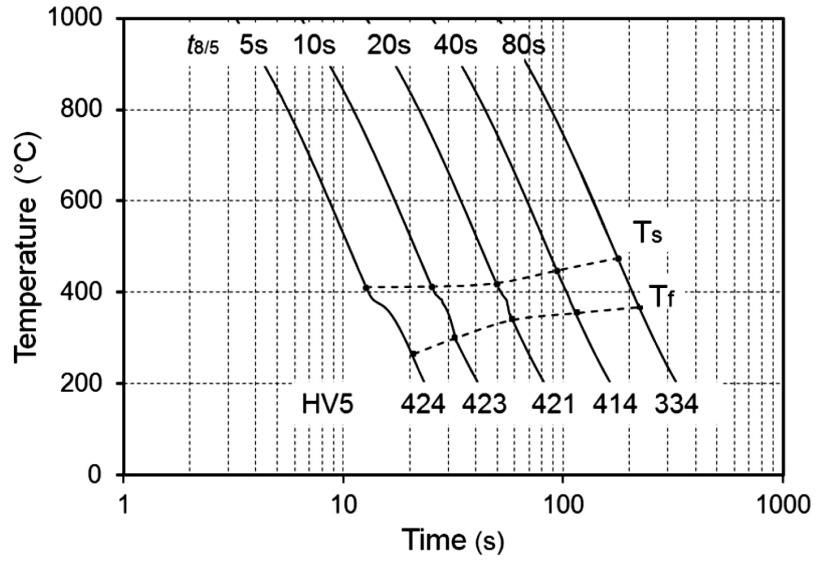

Figure 3: Cooling diagram of the simulated weld CG HAZ with $T_{\mathrm{S}}$ and $T_{\mathrm{f}}$ temperature
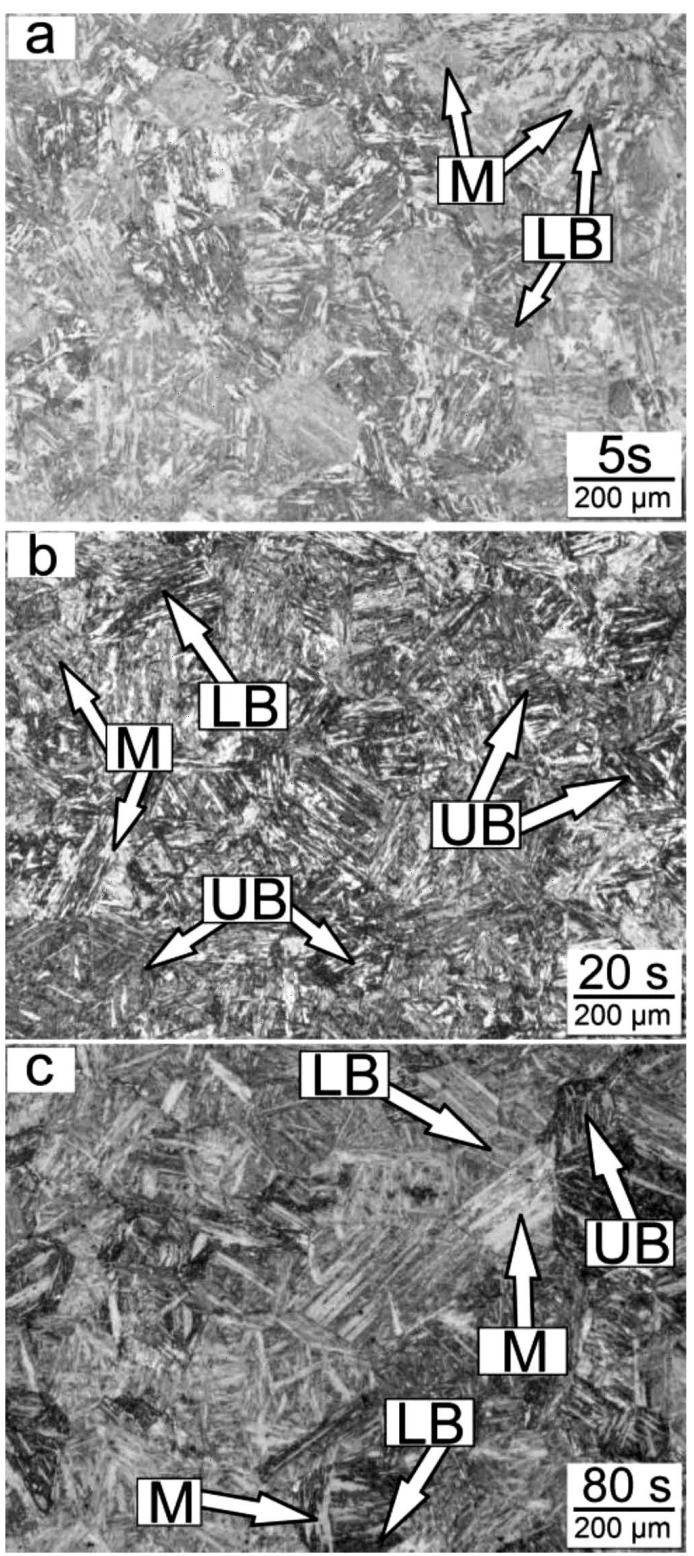

Figure 4: Optical micrographs of the simulated CG HAZ samples at different $t_{8 / 5}(\mathrm{M}$ - martensite; LB - lower bainite, UB - upper bainite) 
Dependence of the simulated CG HAZ HV5 hardness on the cooling time $t_{8 / 5}$ for the investigated experimental steel is given in Figure 3. The average hardness of the experimental S1100Q steel is $446 \mathrm{HV}$ and is the result of the quenched and tempered martensitic microstructure.

The application of a simulated thermal cycle with the cooling times $t_{8 / 5}$ of $5 \mathrm{~s}, 10 \mathrm{~s}$ and $20 \mathrm{~s}$ softens the steel, where the sample hardness drops to 424 HV5, 423 HV5, and $421 \mathrm{HV} 5$, respectively, all being below the hardness of the base metal. As the cooling time $t_{8 / 5}$ increases to $80 \mathrm{~s}$, the hardness further decreases to 334 HV5. The decease of hardness can be attributed to the formation of bainite.

\subsection{Microstructure}

A tempered martensite microstructure of the experimental steel (base metal BM) is presented in Figure 1. Figure 4 shows microstructure of the simulated $\mathrm{CG}$ HAZ samples with cooling times $t_{8 / 5}$ of $5 \mathrm{~s}, 20 \mathrm{~s}$ and $80 \mathrm{~s}$. The microstructure consists of lower bainite and martensite in the 5 samples with a consistently increasing amount of upper bainite as the cooling times increase. All the microstructures are coarse grained, as in- tended by the thermal cycles, in comparison with fine-grained unaffected base metal. The simulation peak temperature of $1350{ }^{\circ} \mathrm{C}$ and a sufficient holding time ensure complete re-austenisation and rapid grain growth that is typical for the CG HAZ.

The prior austenite grain boundaries are still noticeable under the light microscope, but become more apparent under the scanning electron microscope (SEM).

Figure 5a shows the tempered martensite microstructure of base metal (Figure 1). Figure 5b to and 5d shows SEM images of microstructures corresponding to the simulated samples. The carbide precipitates can be clearly observed in the SEM images, the slow natural cooling at lower temperatures allows for some self-tempering of the martensite as small tempering carbides are visible. The fine precipitates are located mainly inside the martensite laths and in lower bainite in Figure 5b, while the slightly larger carbides in Figure 5d belong to the upper bainite.

In a lath martensitic structure, a prior austenite grain is divided into packets of parallel laths, containing extended parallel blocks, and those blocks are further sub-divided by laths, among which there are low-angle
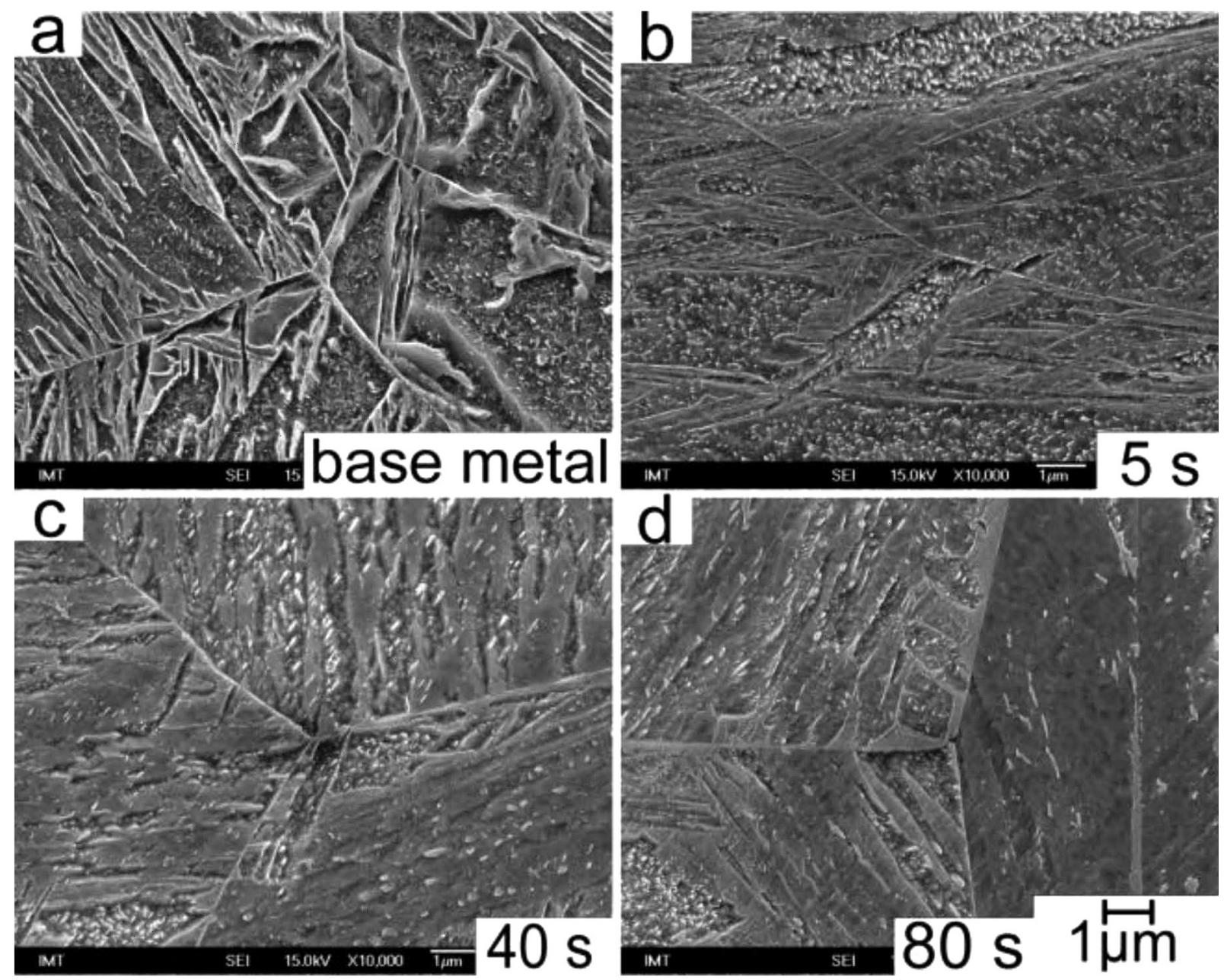

Figure 5: SEM images of the base metal and simulated CG HAZ at $t_{8 / 5}$ of $5 \mathrm{~s}, 40 \mathrm{~s}$ and $80 \mathrm{~s}$ 

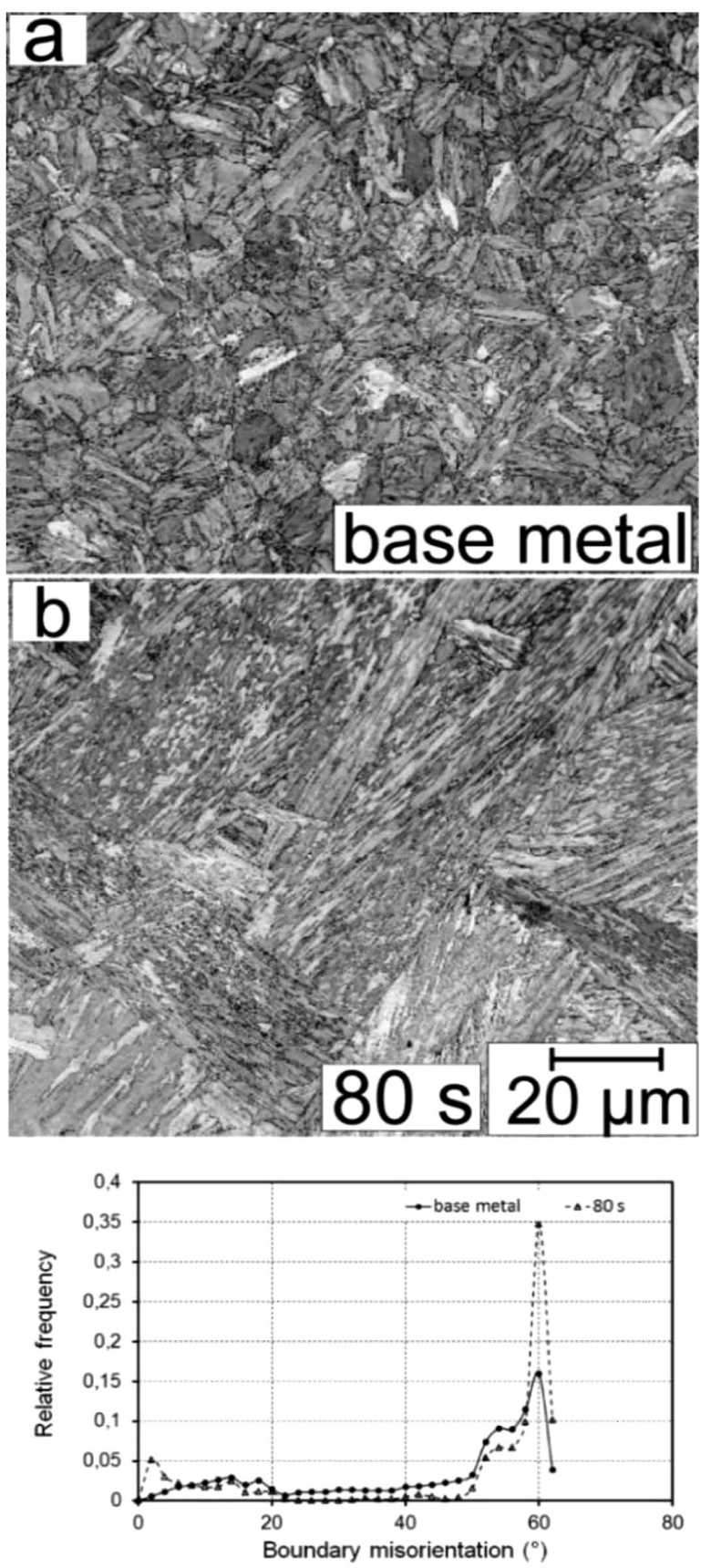

Figure 6: Band contrast images and distribution of grain boundary misorientation

boundaries, while the packet and block boundaries are at high angles. ${ }^{15,16}$

Figure 6 shows band contrast images of the base metal (Figure 6a) and the simulated HAZ at $1100{ }^{\circ} \mathrm{C}$ with a slow cooling of $80 \mathrm{~s}$ (Figure $\mathbf{6 b}$ ), as well as the distribution of the grain-boundary misorientation of both microstructures (Figure 6c). As the base metal shows small equiaxed prior austenite grains (PAG) and a typical martensitic sub-grain structure, the microstructure of the simulated HAZ shows an evident increase of PAG, packets, and blocks, and correspondingly longer laths. Re- garding the grain misorientation angles, the base metal shows a lower ratio of low-angle boundaries $\left(<5^{\circ}\right)$, an almost constant share of boundaries with misorientation angles between $5^{\circ}$ and $45^{\circ}$ with a slight increase between $10^{\circ}$ and $20^{\circ}$, and an increased share of boundaries with discrete misorientation angles of $55^{\circ}$ and $60^{\circ}$. On the other hand, the simulated HAZ microstructure has a sharp increase of grain-misorientation angle of around $2^{\circ}$ (lath boundaries), a nearly linear decrease of share up to $22^{\circ}$, almost no grain boundaries with misorientation angle between $22^{\circ}$ and $50^{\circ}$, then similarly to the base metal, and an increased share of boundaries with discrete misorientation angles of $55^{\circ}$ and $60^{\circ}$. The highest share of boundary misorientation angles is at $60^{\circ}$, which represents the prior austenite, packet, and block boundaries.

\section{CONCLUSIONS}

The focus of this investigation was on the behaviour of the experimental steel's coarse-grained heat-affected zone, which, in real welds, is desired to be as narrow as possible.

The dilatometry analysis of the phase transformations by cooling time was used as a first step of the weldability assessment. The microstructure of the CGHAZ simulated samples was evaluated with optical and a scanning electron microscopy. The main conclusions regarding the investigation of the experimental steel are:

Changes in the microstructure among different $t_{8 / 5}$ simulation samples were mainly an increase of lower and upper bainite share and a decrease in the amount of martensite.

The HV5 hardness of the simulated HAZ samples decreased by 112 HV5 from the base metal for the cooling time $t_{8 / 5}$ of $80 \mathrm{~s}$. The simulation cooling rate was slow enough to induce the start of the re-tempering process, which causes the hardness to drop.

The results of this investigation suggest that the $t_{8 / 5}$ of the investigated experimental steel CG HAZ should be between $5 \mathrm{~s}$ and $40 \mathrm{~s}$. However this is preliminary assessment based on the data available so far.

Further investigations of the experimental steel will be carried out on a weld simulator, making it possible for tensile test and Charpy notch toughness specimens to be produced. The microstructure transformation of samples in continuous cooling are in the temperature range between $476{ }^{\circ} \mathrm{C}$ and $265{ }^{\circ} \mathrm{C}$, thus thermal simulation with continuous cooling will be carried between $500{ }^{\circ} \mathrm{C}$ and $200{ }^{\circ} \mathrm{C}$.

\section{Acknowledgment}

This research was made as a part of ČMRLJ (OP20.03532) research project co-financed by the Republic of Slovenia and the European Union under the European Regional Development Fund. 


\section{REFERENCES}

${ }^{1}$ J. Bernetič, B. Kosec, G. Kosec, Z. Burzić, B. Podlipec, A. Nagode, B. Karpe, S. Kanalec, F. Vodopivec, L. Kosec, Phenomena in penetrating piercing bullets in armored steel plate, Metalurgija, 55 (2016) 1, 95-98

${ }^{2}$ O. Slyvinskyy, Y. Chvertko, S. Bisyk, Effect of welding heat input on heat-affected zone softening in quenched and tempered armor steels, High Temperature Material Processes: An International Quarterly of High-Technology Plasma Processes, 23 (2019) 3, 239-253, doi:10.1615/HighTempMatProc.2019031690

${ }^{3}$ EN 10025-6:2004+A1 Hot rolled products of structural steels - Part 6: Technical delivery conditions for flat products of high yield strength structural steels in the quenched and tempered condition

${ }^{4}$ M. Lomozik, E. Turyk, Mechanical Properties of Welded Joints in Steel S1100QL after Multiple Repair Welding, Biuletyn Instytutu Spawalnictwa, (2018) 3, 7-15, doi:10.17729/ebis.2018.3/1

${ }^{5}$ M. Kowalski, T. Łagoda, F. Żok, V. Chmelko, Fatigue life of butt weldments made of S1100QL steel, Journal of Machine Construction and Maintenance, 113 (2019) 2, 7-13

${ }^{6}$ P. Haslberger, S. Holly, W. Ernst, R. Schnitzer, Microstructure and mechanical properties of high-strength steel welding consumables with a minimum yield strength of $1100 \mathrm{MPa}$, J Mater Sci. 53 (2018) 9, 6968-6979, doi:10.1007/s10853-018-2042-9

${ }^{7}$ M. Dunđer, I. Samardžić, A. Ćorić, G. Salopek, Effects of real welding parameters of high-strength S1100QL steel on hardness and impact energy properties, Metalurgija, 57 (2018) 4, 242-244

${ }^{8}$ J. Górka, D. Janicki, M. Fidali, W. Jamrozik, Thermographic assessment of the HAZ properties and structure of thermos-mechanically treated steel, International Journal of Thermophysics, 38 (2017) 12, doi:10.1007/s10765-017-2320-9
${ }^{9}$ R. P. S. Sisodia, M. Gáspár, Physical simulation-based characterization of HAZ properties in steels. Part 1. High-strength steels and their hardness profiling, Strength of Materials, 51 (2019) 3, 490-499, doi:10.1007/s11223-019-00094-5

${ }^{10}$ M. S. Węglowski, M. Zeman, M. Łomozik, Physical Simulation of Weldability of Weldox 1300 Steel, Materials Science Forum, 762 (2013), 551-555. doi:10.4028/www.scientific.net/MSF.762.551

${ }^{11}$ R. Celin, J. Burja, G. Kosec, A comparison of as-welded and simulated heat affected zone (HAZ) microstructures, Materials and technology, 50 (2016) 3, 455-460, doi:10.17222/mit.2016.006

${ }^{12}$ EN 1011-2, Welding - Recommendations for welding of metallic materials - Part 2: Arc welding of ferritic steels

${ }^{13}$ T. Schaupp, W. Ernst, H. Spindler, T. Kannengiesser, Hydrogen-assisted cracking of GMA welded 960 MPa grade high-strength steels, International Journal of Hydrogen Energy, doi:10.1016/j.ijhydene. 2020.05.077

${ }^{14}$ H. K. D. H. Bhadeshia, R.W. K. Honeycombe. Steels - Microstructure and Properties, 3th ed., Butterworth-Heinemann, Oxford 2006, 299

${ }^{15}$ S. Morito, H. Tanaka, R. Konishi, T. Furuhara, T. Maki, The morphology and crystallography of lath martensite in Fe-C alloys, Acta Materialia, 51 (2003) 6, 1789-1799, doi:10.1016/S1359-6454(02) 00577-3

${ }^{16}$ F. Zhen, K. Zhang, Z. Guo, J. Qu, Effect of martensite structure on mechanical properties of an $1100 \mathrm{MPa}$ grade ultra-high strength steel, Journal of iron and steel research international, 22 (2015) 7, 645-651, doi:10.1016/S1006-706X(15)30052-2 